\title{
Primary Fiscal Performance, Economic Growth, and Public Debt in Lebanon
}

Carole Ibrahim

\begin{abstract}
Lebanese public debt has been accumulating since 1990, after the end of the civil war. Recently, concerns about the ability of the government to keep servicing its debt have emerged, particularly because the debt-to-GDP ratio reached almost $147 \%$ at the end of 2018. This study aims to examine whether a cointegrating relationship exists among primary fiscal performance, real economic growth, and public debt in Lebanon using an autoregressive distributed lag (ARDL) model between 2000 and 2018. The ARDL results suggest the non-existence of a cointegrating relationship and hence the unsustainability of the Lebanese public debt. The evidence of the short-run estimation indicates that better primary fiscal performance and a higher economic growth rate reduce Lebanese public debt in the short run. This study proposes that immediate reforms that increase the primary fiscal surplus and attract investors are crucial to prevent a debt crisis in the country.
\end{abstract}

KEY WORDS: $\quad$ Primary fiscal performance, public debt, ARDL, economic growth, Lebanon.

JEL Classification: C22, H62, H63.

School of Business Administration, American University in Dubai, Dubai, UAE / Law School, Saint Joseph University, Dubai, UAE

\section{Introduction}

Public debt accumulation is a problem that currently affects many economies, including Lebanon. High public debt levels crowd out private investment by absorbing private savings. The crowdingout effect may also result from the rise in interest rates caused by deficit spending and the expectations of higher taxes in the future. Governments can reduce their spending to offset the increase in interest payments and reduce fiscal deficits. However, when governments choose to reduce their capital expenditures, the output level and economic growth decrease. Governments can also increase tax levels to increase their revenues. Nevertheless, an increase in tax levels can distort the economy, especially when the economy is stagnant, and the purchasing power of the majority of families is already low. Impartial and fair taxes should reduce

Correspondence concerning this article should be addressed to: Carole Ibrahim, Dubai, UAE.

E-mail: carole-ibrahim@hotmail.com these distortions.

Governments can also borrow to finance their spending on interest payments. However, a growing public debt may lead to a debt explosion, especially when the debt is financed by foreigners. The Lebanese public debt in foreign currency reached $38.2 \%$ of the total public debt at the end of 2017 (Association of Banks in Lebanon, 2017). Interest payments to foreigners and wide fiscal deficits raise concerns about a public debt crisis in Lebanon. Neaime (2004) shows that the Lebanese fiscal deficits and public debt are unsustainable, and a fiscal crisis could lead to a currency and banking crisis. Saad (2011) also finds weak sustainability for the public debt in Lebanon.

However, policymakers are reacting passively to the public debt issue, financing the country's debt servicing by issuing additional debts, which further increases the risk of a debt explosion. Effective and structural reforms aimed at reducing public spending, fiscal deficits, and public debt have been almost nonexistent in Lebanon. 
This study adds to the existing literature on the Lebanese public debt by using a different and recent timespan to test whether the public debt in Lebanon remains unsustainable, particularly because the debt-to-GDP ratio has been increasing since 2012. In addition, this paper contributes to the literature by using a different methodology to examine the sustainability of the Lebanese public debt. The study uses the autoregressive distributed lag (ARDL) technique to test the long-term cointegrating relationship between primary fiscal balance, which represents the difference between the overall fiscal balance and debt servicing, real economic growth, and public debt, and to quantify the impact of each regressor on the public debt level. The paper also aims to identify policies that should be implemented to avoid a debt crisis in case the debt is found to be unsustainable.

The rest of this paper is structured as follows: the next section reviews the economic situation in Lebanon over the past two decades. After a literature review, section 4 presents the data and methodology used in this study. The results of the cointegration analysis and the short-run dynamics are discussed in section 5 . The last section concludes the paper.

\section{The Lebanese Economy}

Lebanon has one of the highest public debts in the world. After the end of the civil war in 1990, massive infrastructure damage, high inflation rates, and depreciation of the Lebanese Pound (LBP) characterized the economy.

To restore confidence in the country, Lebanon initiated a massive reconstruction plan, and the Central Bank in Lebanon implemented restrictive monetary policies to stabilize the exchange rate and reduce the price level. However, the restrictive policies exerted upward pressure on domestic interest rates. Public debt began to accumulate, and a heavy debt service burden arose due to the higher interest costs. Between 1993 and 1999, the Lebanese gross public debt soared dramatically by an annual average of $64 \%$, from 6,297 billion LBP in 1993 to 30,478 billion LBP in 1999. During the same period, the debt-to-GDP ratio rose from $45 \%$ in 1993 to $117 \%$ in 1999 . The Lebanese public debt continued its upward trend, and gross public debt increased by an annual average of
11.2\% between 2000 and 2005, from 35,363 billion LBP in 2000 to 55,106 billion LBP in 2005. During that period, the debt-to-GDP ratio increased from $136 \%$ in 2000 to $170 \%$ in 2005 . Shares of $40 \%$ and $49 \%$ of total government expenditures were assigned to servicing the debt in 2000 and 2001, respectively. After 2001, this share declined gradually to reach $35 \%$ in 2005 (Ministry of Finance, 2019). After the July War in 2006, the growth rate of the Lebanese gross public debt slowed to an annual average of $7.8 \%$ between 2007 and 2013, and the gross debt-to-GDP ratio declined from $165 \%$ to $128 \%$ due to the higher primary fiscal surpluses (Figure 1).

During the same period (2007-2013), the nominal and real GDP increased by an annual average of $11.5 \%$ and $2.4 \%$, respectively (Figure 2). The stable political climate following the election of a new president in 2008 and the Doha Accord attracted more foreign investment and increased the development of the real estate sector. This favorable climate explains the higher growth rates.

However, the economy has been stagnant since 2015. The real GDP growth rate did not exceed $0.56 \%$ on average per year during the period 2015-2018. In addition, the gross public debt increased by almost $20 \%$, from 103,863 billion LBP to 124,908 billion LBP during the same period (Figure 1). Investors demand high-risk premiums to hold Lebanese debt instruments because of the ongoing political instability and due to concerns about the ability of the government to reduce the overall fiscal deficit and continue servicing its debt. The government's reluctance to introduce structural reforms to public finance and the increase in interest payments, which absorb approximately $63 \%$ of tax revenues and $9.7 \%$ of GDP, explain the increase in debt burden (Association of Banks in Lebanon, 2017). In 2018, the gross debt-to-GDP ratio reached $147 \%$, and $32 \%$ of total government expenditures were allocated to servicing the debt (Ministry of Finance, 2019).

Government spending on electricity, wages and salaries exhausts a considerable share of public revenues. In 2018, government expenditures on electricity represented $10 \%$ of total government spending (Ministry of Finance, 2019). Nevertheless, capital expenditures represent a minor fraction of total public spending. In 2016, only $5.1 \%$ of total government expenditures were allocated to investment 


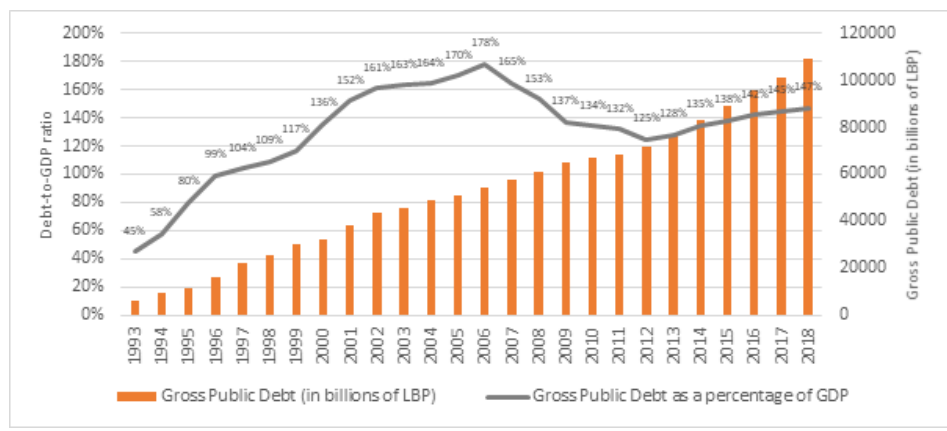

Figure 1. Gross public debt (in billions of LBP) and gross public debt as a percentage of GDP between 1993 and 2018.

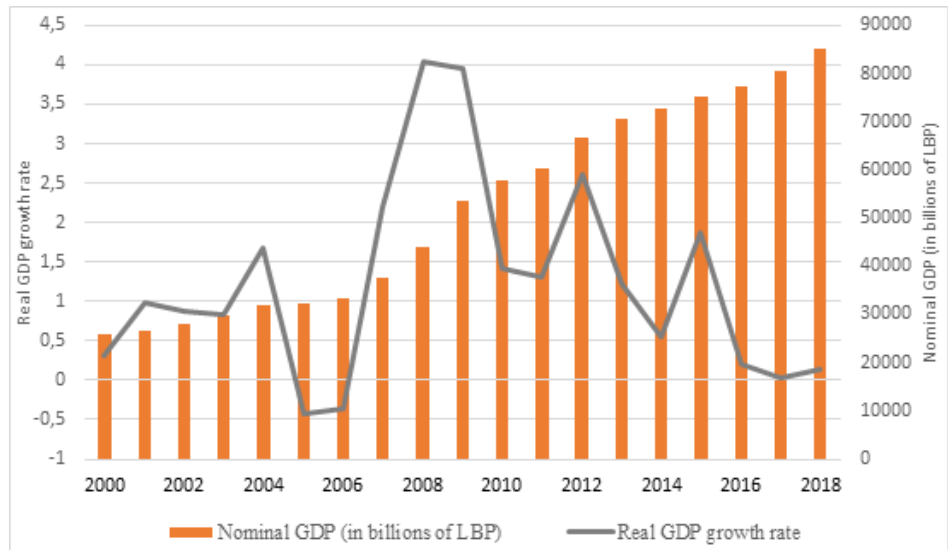

Figure 2. Nominal GDP (in billions of LBP) and real GDP growth rate between 2000 and 2018.

Source: Central Administration of Statistics 
spending (Association of Banks in Lebanon, 2017).

The high current expenditures, coupled with a low level of investment expenditures, explain the low levels of primary fiscal surpluses achieved between 2000 and 2018. The primary fiscal balances were even in deficit in some years during this period. The reluctance of the Lebanese government to implement structural reforms to reduce public spending, coupled with an economic slowdown, led to a deficit of 80 billion LBP in the primary fiscal balance in 2018 (Figure 3). During that year, policymakers introduced a capital gains tax of $15 \%$ to be levied on the disposal of real estate property to increase tax revenues, which represent the primary source of total public revenues (Byblos Bank, 2018). The government also increased the value-added tax rate from $10 \%$ to $11 \%$, in addition to increasing the tax rates on corporate profits, dividend distributions, and interest on bank deposits. However, the increase in tax revenues did not offset the increase in current expenditures.

The Lebanese Parliament further increased the tax rates in 2019 and approved new taxes to reduce the fiscal deficit. However, these higher tax rates encourage investors and individuals to evade taxes, which is an already a common phenomenon in the country.

\section{Literature Review}

Since the 1990s, empirical literature studying the relationships among economic growth, fiscal performance, and public debt has emerged. These studies are motivated by the increased debt levels in many developed, emerging, and developing countries and, in some instances, by debt crises.

Many empirical studies examining the sustainability of public debt and the main determinants of its accumulation start with the debt dynamics equation. The below debt dynamics equation shows the components of the debt dynamics in terms of GDP ratio:

$d_{t}=\frac{1+r_{t}}{1+g_{t}} d_{t-1}-P B_{t}$

where $d_{t}$ represents the debt-to-GDP ratio during

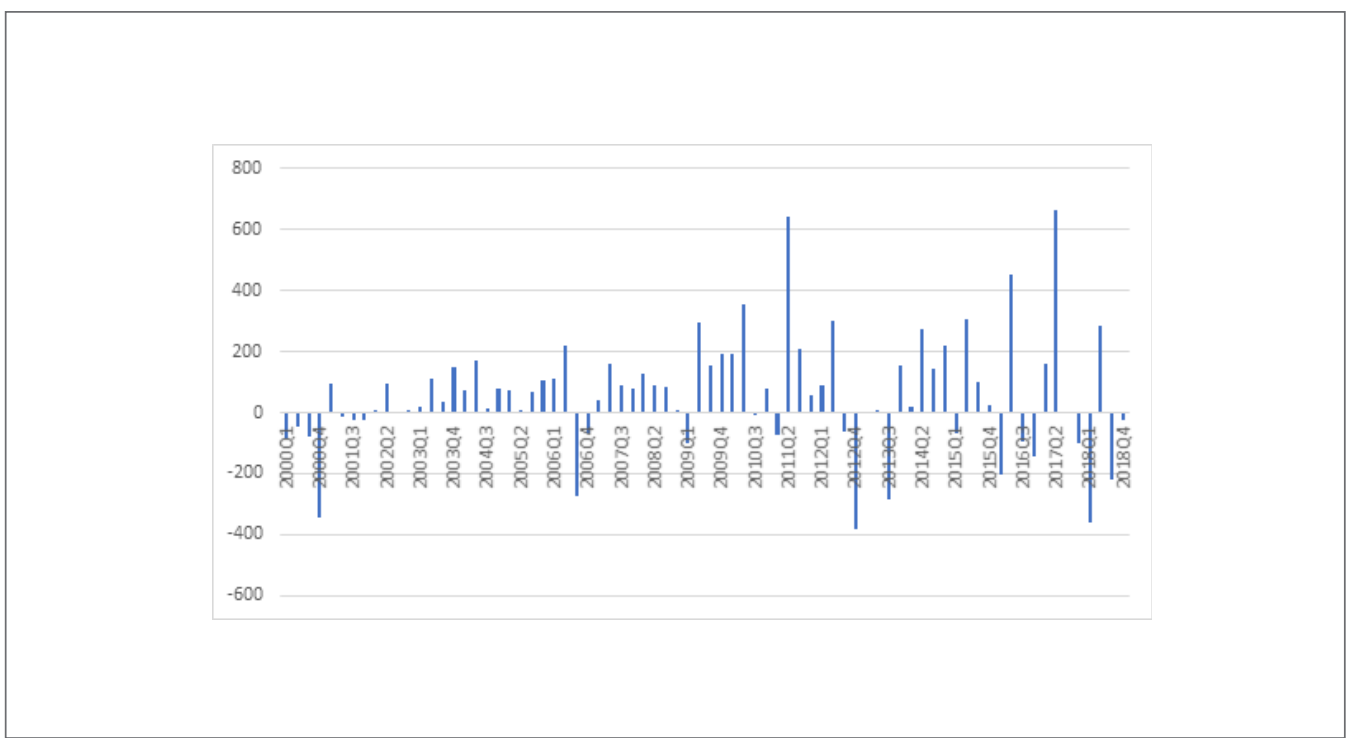

Figure 3. Primary fiscal performance (deficit/surplus) (in billions of LBP) between 2000 and 2018.

Source: Ministry of Finance 
period $\mathrm{t}, \mathrm{rt}$ and $\mathrm{g}_{\mathrm{t}}$ represent the real interest rate and the real economic growth rate, respectively, and $\mathrm{PB}_{\mathrm{t}}$ represents the ratio of the primary fiscal balance to GDP. Equation (1) shows that the debt-to-GDP ratio at the end of year $t$ is a function of the debt-to-GDP ratio of the previous year, augmented by the real interestgrowth differential. The greater the gap between the interest rate and the GDP growth rate is, the higher the debt-to-GDP ratio is, and vice versa, the lower the interest-growth differential is, the lower the debt-toGDP ratio is.

From Equation (1), the decomposition of changes in the debt ratio becomes (Escolano, 2010):

$$
d_{t}-d_{t-1}=\frac{r_{t}}{1+g_{t}} d_{t-1}-\frac{g_{t}}{1+g_{t}} d_{t-1}-P B_{t}
$$

Equation (2) shows that the variation in the public debt ratio depends on the real interest rate, real economic growth rate, and primary fiscal balance. An increase in the primary fiscal deficit and the interestgrowth differential raise the debt-to-GDP ratio. However, a high and increasing debt ratio signals the likelihood of a debt crisis.

Alnashar (2019) applies a debt dynamics decomposition to identify the various drivers of the government debt level in Egypt between 2001 and 2016. The author finds that the primary fiscal deficit is the main contributor to government debt growth and that real GDP growth plays a favorable role in containing the rise of the debt-to-GDP ratio. Alba et al. (2004) also find that persistent fiscal deficits cause rising public debt in Egypt. The authors suggest that a reduction in current expenditures, specifically wages and salaries, as well as reform of the tax system can help reduce the debt.

Sahay (2005) employs a debt accounting exercise to analyze the sources of public debt accumulation in six highly indebted Caribbean countries. The findings show that during the period 1998-2003, the average public debt-to-GDP ratio increased by $8.5 \%$. Deterioration of the primary fiscal balance explains $4.5 \%$ of this increase, while output growth and interest payments explain 3.3\%. Tanzi and Fanizza (1995) perform a panel data analysis on 18 industrial countries for the period 1970-1993 to examine the impact of real economic growth and primary government deficit on debt-to-GDP ratio. They conclude that a country needs to run a large primary surplus to stabilize the debt. Similarly, by performing a debt decomposition exercise in 19 advanced economies for the period 1880-2007, Abbas et al. (2011) find that the primary fiscal surplus plays a crucial role in debt reduction.

A study conducted by the World Bank (2005) uses the debt dynamics equations to test the impact of primary surpluses, real growth rates, and real interest rates on the debt-to-GDP ratio in 21 market-access countries for the years 1991-2002. The study suggests that real GDP growth and primary fiscal surpluses reduce public debt.

In addition, using a generalized method of moments (GMM) regression model, Vighneswara (2015) finds that for every $1 \%$ growth in real GDP, government debt declines by $0.27 \%$ to $0.64 \%$ in advanced economies, $1.03 \%$ to $1.31 \%$ in emerging economies, and $1.43 \%$ to $1.63 \%$ in developing economies.

Following the debt dynamics equation, this study examines the main determinants of the Lebanese public debt by applying the ARDL model to measure the impact of the primary fiscal surplus, real economic growth, and real interest rate on the Lebanese debt ratio. In addition, the ARDL model examines the sustainability of the Lebanese public debt. Performing such an analysis in Lebanon is particularly important because the debt-to-GDP ratio in Lebanon has been increasing since 2012 and reached 147\% in 2018, raising new concerns about the government's ability to keep servicing its debt.

One empirical framework examines debt sustainability by employing cointegration analysis. Neaime (2010) uses the Johansen cointegration test and the Present Value Constraint model to examine debt sustainability in different MENA countries. The author concludes that public debt is sustainable in Tunisia, unsustainable in Jordan and Turkey, and weakly sustainable in Egypt. Prohl and Schneider (2006) apply the Engle-Granger test and Pedroni panel cointegration test to examine debt sustainability by investigating the existence of cointegration between the primary deficit and debt-to-GDP ratio in fifteen European countries covering the period 1970-2004. The Engle-Granger test applied to individual country data confirms the cointegration for a large group of countries. Additionally, the results of the Pedroni panel cointegration test confirm that primary budget deficits 
and public debt are cointegrated and thus that the public debt is sustainable in most European countries. This study uses a different cointegration technique to test the long-term cointegrating relationship among the primary fiscal deficit, economic growth, and Lebanese public debt. If a cointegrating relationship can be detected, then it can be concluded that the Lebanese public debt is sustainable.

\section{Methodology}

This study uses a cointegration approach to examine the sustainability of Lebanese public debt and to estimate the impact of primary fiscal performance, real economic growth, and real interest rates on loans in LBP on debt-to-GDP ratio. The Lebanese public debt has been growing since the early 1990s; however, the availability of data limits the estimation period to the past two decades: quarterly data series for 2000Q12018Q4 are used.

The growth rate of real GDP is used to represent economic growth. Annual nominal GDP values are collected from the Central Administration of Statistics (2019) in Lebanon and interpolated to quarterly values using the quadratic interpolation method. These values are deflated by the CPI index to be expressed in real terms.

Primary fiscal performance is used instead of total fiscal performance to exclude debt servicing (including interest payments) and thus to better capture changes in fiscal policy. Primary fiscal performance is represented as a percentage of nominal GDP. Data for the primary fiscal balance (deficit/surplus) are obtained from the Ministry of Finance (2019).

Interest rates on loans in local currency are estimated to examine whether high levels of interest rates on loans issued by Lebanese commercial banks lead to a slower increase in public debt. Time series data for nominal interest rates are collected from the Central Bank of Lebanon (2019). Interest rate values are expressed in real terms.

Gross public debt is represented as a percentage of nominal GDP. Time series data for Lebanese gross public debt are collected from the Central Bank of Lebanon (2019).

This study aims to examine whether a long-term cointegrating relationship exists among primary fiscal performance, economic growth, and real interest rates on the one hand and public debt in Lebanon on the other hand. Various techniques can be used to detect the long-run relationship, such as the Johansen cointegration test (1991) or Pedroni test (2004), which is used by Prohl and Schneider (2006). However, this paper uses the ARDL model. The advantage of this technique is that it can estimate whether cointegration exists among variables in the long run, even when the variables are of different orders. In addition, this model separates the short-run and long-run relationships between the regressors and the dependent variable (Pesaran et al. , 1999). In our model, public debt is the dependent variable; primary fiscal performance, economic growth, and real interest rates are the regressors. A required condition to apply the ARDL model is that each variable is stationary of either order I(0) or order I(1). If any variable is integrated of order I(2), the model cannot be applied. An augmented Dickey-Fuller (ADF) (Dickey \& Fuller, 1979) unit root test is performed to test the stationarity of each variable and to determine its order of integration. Moreover, the Akaike Information Criterion (AIC) is used to estimate the optimal lag of each variable in the ARDL model.

The reparameterization of the ARDL model into the error correction model (ECM) is shown in Equation (3). The estimation of the ECM is crucial to study the short-run impact of real economic growth, real interest rates, and primary fiscal performance on Lebanese public debt.

$\Delta \mathrm{y}_{\mathrm{t}}=\mathrm{a}_{0}+\sum_{i=1}^{p} \alpha_{i} \Delta y_{t-i}+\sum_{j=1}^{k} \sum_{i=0}^{q} \beta_{i} \Delta \mathrm{X}_{\mathrm{j}, \mathrm{t}}+\theta \mathrm{ECT}_{\mathrm{t}-1}+\varepsilon_{\mathrm{t}}$

In Equation (3), $\Delta$ is the difference operator, $y_{t}$ represents public debt, $\mathrm{X}_{\mathrm{j}, \mathrm{t}-\mathrm{i}}$ is the vector of regressors with $j=1, \ldots, k$ regressors, and $a_{0}$ is the intercept. $\alpha_{i}$ is the coefficient of lagged public debt, and $\beta_{\mathrm{j}}$ represents the coefficients of lagged primary fiscal performance, real economic growth rate, and real interest rate. $\alpha_{i}$ and $\beta_{j}$ identify the short-run impact of each regressor on public debt. $\mathrm{p}$ and $\mathrm{q}$ are the optimal lag orders determined by the AIC. $\theta_{\mathrm{i}}$ represents the speed of adjustment toward the long-run equilibrium, $\mathrm{ECT}_{\mathrm{t}-1}$ is the error correction term that results from the long-run relationship, and $\varepsilon_{\mathrm{t}}$ represents the error term.

Before running ECM regression, an F bound test is performed to examine whether a long-term cointegrat- 
ing relationship exists between the regressors and the public debt in Lebanon.

After including our variables in Equation (3), the ARDL model can be rewritten as follows:

$$
\begin{aligned}
& \Delta \text { debt }_{\mathrm{t}}=\mathrm{a}_{0}+\sum_{i=1}^{p} \alpha_{\mathrm{i}} \Delta \mathrm{debt}_{\mathrm{i} i \mathrm{i}}+\sum_{i=0}^{q} \beta_{\mathrm{l}} \Delta \mathrm{fisc}_{\mathrm{ti}}+\sum_{i=0}^{q} \beta_{z} \Delta \mathrm{GDP}_{\mathrm{ti}} \\
& +\sum_{i=0}^{q} \beta_{3} \Delta \mathbf{r}_{t-1}+\delta_{1} \operatorname{debt}_{t-1}+\delta_{2} \text { fisc }_{t-1}+\delta_{3} \mathrm{GDP}_{\mathrm{t}-1}+\delta_{4} \mathrm{r}_{\mathrm{t}-1}+\varepsilon_{\mathrm{t}}
\end{aligned}
$$

where debt denotes the public debt as a percentage of GDP, Fisc represents the primary fiscal performance as a percentage of GDP, GDP represents the real economic growth rate, and $\mathrm{r}$ represents the real interest rate on loans in local currency.

$\delta_{1}, \delta_{2}, \delta_{3}$, and $\delta_{4}$ denote the long-run relationships. Following Pesaran et al. (1999), the null and alternative hypotheses to be tested are as follows:

$\mathrm{H}_{0}: \delta_{1}=\delta_{2}=\delta_{3}=\delta_{4}=0$, no cointegration exists between variables.

$\mathrm{H}_{1}: \delta_{1} \neq \delta_{2} \neq \delta_{3} \neq \delta_{4} \neq 0$, cointegration exists between variables.

Each hypothesis is tested using the F test. Pesaran et al. (1999) provide bounds on the critical values for the distribution of the F-statistic. The null hypothesis is accepted when the computed F-statistic is less than the $\mathrm{I}(0)$ critical value bound and rejected when the computed F-statistic is greater than the $\mathrm{I}(1)$ critical value bound. When the F-statistic is between the $\mathrm{I}(0)$ and I(1) bound values, the relationship is inconclusive.

If a cointegration among primary fiscal balance, real economic growth, real interest rate, and debt-to-GDP ratio can be detected, then it can be concluded that the Lebanese public debt is sustainable.

\section{Results and Discussion}

\subsection{Unit Root Test}

As mentioned earlier, the stationarity of each variable included in the ARDL equation is tested using the ADF unit root test. The null and alternative hypotheses to be tested are as follows:

$\mathrm{H}_{0}$ : the variable has a unit root vs. $\mathrm{H} 1$ : the variable does not have a unit root.

The results presented in table 1 provide strong evidence that primary fiscal performance and real GDP growth rate are stationary at level $\mathrm{I}(0)$. Hence, the null hypothesis of the existence of unit roots can be rejected. However, public debt as a percentage of GDP and real interest rate are nonstationary at level, and the null hypothesis of the existence of a unit root is accepted. Nevertheless, when these two variables are converted into the first difference, they become stationary I(1). These results are reported in Table 2.

ARDL is the best model to use in this study to detect the long-run relationship because the variables are integrated of different orders.

\subsection{ARDL Results}

The model selection criteria are based on the AIC. The top model suggested by the AIC is ARDL $(2,1,4,2)$, in which the optimal lag length of public debt and real interest rate is two lags each, the optimal lag length of primary fiscal performance is $1 \mathrm{lag}$, and the optimal lag length of real GDP growth rate is four lags.

The results of the F-statistic bound test are shown in table 3, where $\mathrm{k}$ represents the number of regressors. The calculated F-statistic is 3.03, which lies within the $\mathrm{I}(0)$ and $\mathrm{I}(1)$ bound values at $5 \%$ and $10 \%$ levels of significance. Thus, the relationship among primary fiscal performance, real GDP growth rate, real interest rate, and public debt is inconclusive at $5 \%$ and $10 \%$ levels of significance. However, the F-statistic is lower than the $\mathrm{I}(0)$ critical value bound at $2.5 \%$ and $1 \% \mathrm{lev}$ els of significance. Hence, the null hypothesis cannot be rejected, and it can be concluded that no cointegrating relationship exists between the regressors and the Lebanese public debt. Therefore, the Lebanese public debt is unsustainable.

The results of the ARDL ECM regression are shown in table 4. The reparametrized ARDL ECM shows the short-run impact of each independent variable on public debt. The primary fiscal performance has a negatively significant influence on public debt in the short term: an increase in primary fiscal surplus reduces public debt in Lebanon. This result is in line with the findings of Tanzi and Fanizza (1995) and Alnashar (2019). The real GDP growth rate is negatively significant when differenced, and lag 2, and lag 3 differenced. Thus, an increase in real economic growth reduces the public debt in the short run. This result validates the results of Vighneswara (2015) and the World Bank (2005). The real interest rate has a significant negative impact on public debt in the short run when lag 1 differenced. Thus, an increase in interest rates reduces the growth in public debt. 
Table 1. Results of the ADF Unit Root Test (at Level Specification)

\begin{tabular}{lcccc}
\hline \multirow{2}{*}{ Variable } & \multicolumn{3}{c}{ ADF Unit Root Test at Level Specification } \\
\cline { 2 - 5 } & \multicolumn{2}{c}{ (with intercept) } & \multicolumn{1}{c}{ (with trend and intercept) } \\
\cline { 2 - 5 } & t-stat & p-value & t-stat & p-value \\
\hline Public Debt (as a \% of GDP) & -1.58 & 0.48 & -2.32 & 0.41 \\
Primary Fiscal Performance (as a \% of GDP) & -8.14 & $0.00^{* *}$ & -8.09 & $0.00^{* *}$ \\
Real GDP Growth Rate & -7.16 & $0.00^{* *}$ & -7.11 & $0.00^{* *}$ \\
Real Interest Rate & -2.38 & 0.14 & -1.35 & 0.86 \\
\hline
\end{tabular}

Note: ${ }^{*}$ denotes the rejection of the null hypothesis (existence of unit roots) at a $5 \%$ level of significance.

Table 2. Results of the ADF Unit Root Test (First Difference)

\begin{tabular}{lcccc}
\hline Variable & \multicolumn{3}{c}{ ADF Unit Root Test at Level Specification } \\
\cline { 2 - 5 } & \multicolumn{2}{c}{ (with intercept) } & (with trend and intercept) \\
\cline { 2 - 5 } & t-stat & p-value & t-stat & p-value \\
\hline Public Debt (as a \% of GDP) & -4.40 & 0.00 & -4.42 & 0.00 \\
Real Interest Rate & -11.97 & 0.00 & -12.35 & 0.00 \\
\hline
\end{tabular}

Note: ${ }^{*}$ denotes the rejection of the null hypothesis (existence of unit roots) at a $5 \%$ level of significance.

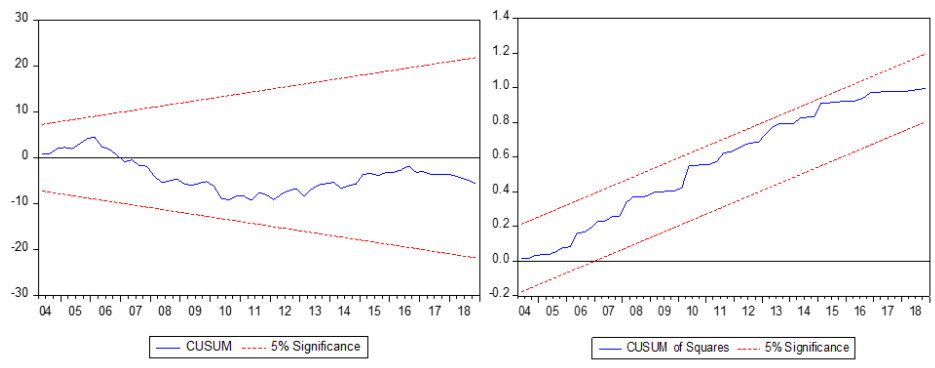

Figure 4. Cumulative sum (CUSUM) and cumulative sum of squares (CUSUMSQ).

Note: Residual values are within the confidence level bounds. 
The short-run estimation shows that running a continuous primary fiscal surplus is crucial to reduce the Lebanese debt-to-GDP ratio. Large and growing primary fiscal deficits are the primary drivers of unsustainable debt levels. Fiscal deficits lead to more debt issuance and hence increase the debt burden. In addition, a sustained higher economic growth is important to reduce the Lebanese public debt. Thus, the ARDL results suggest that implementing policies to achieve continuous primary fiscal surplus and promote economic growth are vital to achieve sustainable debt levels and avoid a debt crisis.

Two diagnostic tests are performed to check the validity of the estimated ARDL model. The Breusch-Godfrey serial correlation LM test and Breusch-PaganGodfrey test are used to check for serial correlation and heteroskedasticity, respectively. The results in table 5 indicate that the residuals are serially uncorrelated and homoscedastic.
In addition, the cumulative sum (CUSUM) and the cumulative sum of squares (CUSUMSQ) tests are used to examine the stability of the estimated model. Figure 4 shows that the model is stable. All the residual values are within the confidence level bounds.

\section{Conclusion}

This study uses the ARDL technique to investigate the relationships among real GDP growth rate, primary fiscal performance, real interest rates on loans in local currency, and public debt in Lebanon between the years 2000 and 2018. The results confirm that no cointegrating relationship exists and that the Lebanese debt is unsustainable. In addition, the short-run estimation shows that an increase in primary fiscal surplus and economic growth significantly reduces Lebanese public debt. Thus, the country needs to run continuous primary fiscal surpluses and achieve higher growth levels to reduce the debt-to-GDP ratio to more sustainable levels and avoid a debt crisis.

Table 3. Results of the F-Bounds Test (Unrestricted Constant, No Trend)

\begin{tabular}{lcccc}
\hline & \multicolumn{4}{c}{ F-Bounds Test- Null Hypothesis: No level relationship } \\
\hline & Value & Significance & $\mathbf{I ( 0 )}$ & $\mathbf{I ( 1 )}$ \\
\hline F-Statistic & 3.03 & $10 \%$ & 2.37 & 3.2 \\
$\mathrm{k}$ & 3 & $5 \%$ & 2.79 & 3.67 \\
& & $2.5 \%$ & 3.15 & 4.08 \\
& & $1 \%$ & 3.65 & 4.66 \\
\hline
\end{tabular}

Note: I(0) and I(1) represent the critical value bounds.

Table 4. Results of the ARDL Error Correction Regression (Short-term Estimation)

\section{Dependent Variable: D (Public Debt as a \% of GDP)}

\begin{tabular}{lcccc}
\hline Variable & Coefficient & Standard Error & t-stat & p-value \\
\hline Public Debt (lag 1 differenced) & $0.29^{* * *}$ & 0.09 & 2.99 & 0.00 \\
Primary Fiscal Performance (differenced) & $-0.97^{*}$ & 0.54 & -1.77 & 0.08 \\
Real GDP Growth Rate (differenced) & $-0.42^{* * *}$ & 0.11 & -3.51 & 0.00 \\
Real GDP Growth Rate (lag 1 differenced) & 0.01 & 0.13 & 0.08 & 0.93 \\
Real GDP Growth Rate (lag 2 differenced) & $-0.29 * * *$ & 0.11 & -2.55 & 0.01 \\
Real GDP Growth Rate (lag 3 differenced) & $-0.30^{* * *}$ & 0.09 & -3.06 & 0.00 \\
Real Interest Rate (differenced) & 0.36 & 0.26 & 1.41 & 0.16 \\
Real Interest Rate (lag 1 differenced) & $-0.68^{* *}$ & 0.27 & -2.50 & 0.01 \\
\hline
\end{tabular}

Note: I(0) and I(1) represent the critical value bounds. 
Table 5. Residual Diagnostic Test Results

\begin{tabular}{lcc}
\hline Test & F-stat & p-value \\
\hline Breusch-Godfrey Serial Correlation LM Test & 0.61 & 0.65 \\
Breusch-Pagan-Godfrey Test & 1.07 & 0.39
\end{tabular}

Note: Residuals are serially uncorrelated and homoscedastic (p-value $>5 \%$ ).

Higher surpluses in the primary balance secure fiscal sustainability, decrease interest costs, and reduce public debt. Therefore, policymakers should implement immediate reforms to cut spending and increase revenues. In addition, they should implement policies to attract more investment and stimulate economic growth.

\section{References}

Alba, P., Al-Shawarby, S., \& Farrukh, I. (2004). Fiscal and public debt sustainability in Egypt (Working Paper No. 38). The World Bank. http://documents.worldbank. org/curated/en/587421468770130638/Fiscal-andpublic-debt-sustainability-in-Egypt

Abbas, S.M.A., Belhocine, N., El-Ganainy, A., \& Horton, M. (2011). Historical patterns and dynamics of public debt - Evidence from a new database. IMF Economic Review, 59(4), 717-742. https://doi.org/10.1057/imfer.2011.24

Alnashar, S. (2019). Egypt's government debt: Perpetual deficits and exchange rate depreciations. The World Bank. https://erf.org.eg/publications/egypts-government-debt-perpetual-deficits-exchange-rate-depreciations/

Association of Banks in Lebanon. (2017). The annual report 2017. ABL Periodicals. https://www.abl.org.lb/ english/the-annual-report/edition-2017

Byblos Bank. (2018). Lebanon this week (No. 536). Economic Research \& Analysis Department. https:// www.byblosbank.com/ContentFiles/6504PDF.pdf

Central Administration of Statistics. (2019). National accounts. http://www.cas.gov.lb/index.php/nationalaccounts-en

Central Bank of Lebanon. (2019). Statistics and research Main series. http://www.bdl.gov.lb/webroot/statistics/

Dickey, D., \& Fuller, W. (1979). Distribution of the estimators for autoregressive time series with a unit root. Journal of the American Statistical Association, 74(366), 427-431. https://doi.org/10.1080/01621459. 1979.10482531
Escolano, J. (2010). A practical guide to public debt dynamics, fiscal sustainability, and cyclical adjustment of budgetary aggregates (IMF Technical Notes and Manuals No. 10/02). International Monetary Fund. https://www.imf.org/en/Publications/TNM/Issues/2016/12/31/A-PracticalGuide-to-Public-Debt-Dynamics-Fiscal-Sustainability-and-Cyclical-Adjustment-of-23498

Johansen, S. (1991). Estimation and hypothesis testing of cointegration vectors in gaussian vector autoregressive models. Econometrica, 59 (6), 1551-1580. https://doi.org/10.2307/2938278

Ministry of Finance - Republic of Lebanon. (2019). Economic data \& statistics [Data set]. http://www. finance.gov.lb/en-us/Finance/EDS/Pages/default. aspx

Neaime S. (2004). Sustainability of budget deficits and public debt in Lebanon: A stationarity and co-integration analysis. Review of Middle East Economics and Finance, 2(1), 43-61. https://doi. org/10.2202/1475-3693.1019

Neaime S. (2010). Sustainability of MENA public debt and the macroeconomic implications of the recent global financial crisis. Middle East Development Journal, 2(2), 177-201. https://doi.org/10.1142/ S1793812010000228

Pedroni, P. (2004). Panel cointegration; asymptotic and finite sample properties of pooled time series tests, with an application to the PPP hypothesis. Econometric Theory, 20(3), 597-625. https://doi. org/10.1017/S0266466604203073

Pesaran, M. H., Shin, Y., \& Smith, R. J. (1999). Bounds testing approaches to the analysis of long run relationships (Working Paper No. 46). Edinburgh School of Economics, University of Edinburgh. http://www.econ.ed.ac.uk/papers/id46_esedps. pdf

Prohl, S., \& Schneider, F. (2006). Sustainability of public debt and budget deficit: Panel cointegration analysis for the European Union member countries (Working Paper No. 0610). Johannes Kepler University 
of Linz, Department of Economics. https://www. econstor.eu/bitstream/10419/73195/1/wp0610. pdf

Saad W. (2011). Assessing sustainability of Lebanese public debt: A cointegration analysis approach. International Research Journal of Finance and Economics, 62, 143-156.

Sahay, R. (2005). Stabilization, debt, and fiscal policy in the Caribbean (Working Paper No. 05/26). International Monetary Fund. https://www.imf.org/ external/pubs/ft/wp/2005/wp0526.pdf

Tanzi, V., \& Fanizza, D. (1995). Fiscal deficit and public debt in industrial countries, 1970-1994 (Working Paper No. 95/49). International Monetary Fund. https://ssrn.com/abstract $=883197$

The World Bank. (2005). Public debt and its determinants in market access countries. http://siteresources.worldbank.org/INTDEBTDEPT/ Resources/468980-1225740508953/MACCaseStudiesMar05.pdf

Vighneswara, S. (2015). Government debt and its macroeconomic determinants - An empirical investigation (Working Paper No. 64106). University Library of Munich, Germany. https://papers.ssrn. com/sol3/papers.cfm?abstract_id $=2601875$ 